screening isn't an enormous hassle. It's "relatively painless" and the administrative costs are simply added to physician application fees, he says.

A "very minor percentage" of physicians fail to disclose their criminal records and subsequently are flagged during screening, he adds. "Off the top of my head I can recall four. ... We do 300 full locum applications a year ... so you're dealing with a fraction of $1 \%$."

Most of the hits are for "the usual DUIs [driving under the influence] and perhaps some drug issues in their misspent youth" which generally don't prevent regulators from granting a license. But failing to disclose recent charges and convictions does raise questions about an applicant's character, Schollenberg adds.

Those numbers are surely "really low," Robert says. But there are "unfortunately no statistics because of the inconsistency from one province to the other. It's not really useful to maintain statistics that will give a number of persons that is less than the number of fingers on your two hands."

Theman and Salte say they're unaware of any physicians having lied on an application in Alberta or Saskatchewan, let alone lied about a criminal record. Such a devious character wouldn't escape regulatory scrutiny for long, they say.

"Saskatchewan is a pretty small place and everybody knows everything about everybody. If there is a serious criminal offense and a physician is named somebody will know about it," Salte says. Moreover, "no physician is ever allowed to move from province to province until the regulatory body in the province they're moving from signs a certificate indicating here's our knowledge of this person and they have or haven't been disciplined."

International medical graduates aren't a concern because they're subject to immigration checks, "so the likelihood of someone with criminal past coming in is quite low," he adds.

Schollenberg typically garners more information about an incoming physician from Google than he does from a criminal records check. "I've had letters from people in federal prisons, people who just got out from federal prison and one fellow who got charged in Florida for impersonating a physician, and those were just [cases] where something about the story looked suspicious. And so with Google and a few other sources you can find out enough to tell you this is someone you don't want to deal with."

But such an informal and intuitive method of obtaining information about an applicant is perhaps only of value to a smaller province, Schollenberg adds. "New Brunswick is a lovely place but people from California tend not to decide to come here out of the blue."
Reports of disciplinary action are shared between provinces but information about applicants who were denied licensure or withdrew their applications is inconsistently shared between jurisdictions.

"Part of it is avoiding an overabundance of information," Schollenberg says. "We sometimes get emails from one of the neighbouring provinces saying we've just found out this guy's documents are questionable or something like that. But it's kind of ad hoc."

Robert, though, believes nationwide adoption of mandatory criminal record checks at entry to practice would ensure that no one slips through the seams.

It's not only a matter of due diligence, but ultimately one of "the confidence of the public" in the profession's ability to self-regulate, he adds. "Probably it's a matter of time. Everyone will standardize their process." - Lauren Vogel, CMAJ

\section{CMAJ 2012. DOI:10.1503/cmaj.109-4113}

First of a three-part series:

Part 2: A check a day keeps the bad apple away (www.cmaj.ca/lookup /doi /10.1503/cmaj.109-4114).

Part 3: Are you kidding, doc?

(www.cmaj.ca/lookup/doi/10.1503

/cmaj.109-4115).

\title{
A check a day keeps the bad apple away
}

\section{$\mathrm{M}$} andatory criminal records screening for physicians may be little more than a bow to an unnecessary formality in the eyes of Canadian regulators, but practitioner licensing bodies elsewhere in the world contend such screening is crucial to weeding out bad apples.

Canadian medical regulatory authorities, including ones that perform background checks as a condition of entry to practice, argue that such screening is largely superfluous. They assert that the number of doctors who lie about previous criminal charges or convictions is negligible and could easily be found out through less systematic methods such as self-disclosure (www.cmaj.ca /lookup/doi/10.1503/cmaj.109-4113).

But similar regulatory bodies in the United States, Australia and England assert that background checks identify shady characters who would otherwise slip through the vetting cracks and have proven an invaluable tool in obtaining more rapid treatment for doctors who might, for example, be inclined to seek solutions from a bottle.

"There are not a lot of physicians who have been convicted of a felony. But they do exist and it's incumbent upon us when we license somebody to ensure that they meet the minimum qualifications," says Kathleen Selzler Lippert, executive direc- tor of the Kansas State Board of Healing Arts - one of 45 state medical licensing boards in the US that conduct background checks at entry to practice. "We expect people to be honest and this provides an independent verification."

Some medical regulatory authorities who have introduced background checks as a matter of course were surprised to discover just how many applicants either forgot or lied about their criminal past.

The North Carolina Medical Board wasn't aware it had a "fairly significant problem" until mandatory screening for new applicants was introduced in 2003, says Jean Fisher Brinkley, director of public affairs for the board. Now, there's 
some type of positive hit for "maybe as much as one in five applications," and "it would be fair to say the vast majority of that 10 to 20 percent" had not been disclosing their criminal histories.

State licensing boards do not appear to keep formal statistics on the number of applicants who are denied licensure because of their criminal record. But numerous cases have been reported across the country, Drew Carlson, director of communications for the Federation of State Medical Boards, writes in a statement.

The Oklahoma State Board of Medical Licensure and Supervision, for example, has handled about 10 such cases in the past five years, Executive Director Lyle Kelsey writes in an email.

Meanwhile, the Australian Health Practitioner Regulation Agency rolled out a national screening program for 10 health professions and the 2011 findings indicated that 2992 , or $6 \%$ of health care practitioners, had a criminal history (www.ahpra.gov.au/documents /default.aspx ?record=WD11\%2f6030\& dbid=AP\&chksum=pTM1u6EU\%2bet QIekGFKrfOQ\%3d\%3d). Of those, $15 \%$ were serious enough to potentially affect the practitioner's registration and the agency subsequently imposed conditions on the registration of eight physicians. "The fact that there were any adverse outcomes on someone's registration suggests to us that it's a worthwhile mechanism," says Communications Advisor Nicole Newton.

Physicians in England are also required to undergo criminal records screening to get on regional registration lists in order to treat patients. "At least 130,000 unsuitable people have been prevented from working with vulnerable groups" since England's Criminal Records Bureau opened in 2002, although the bureau doesn't track how many of those were physicians, Kirsty Gelsthorpe, a press officer for England's Department of Health, writes in an email.

Fisher Brinkley says most charges and convictions flagged during screening are for "drug and alcohol related offenses, sometimes with traffic violations mixed in, and occasionally ... domestic violence."

Gelsthorpe notes that such informa-

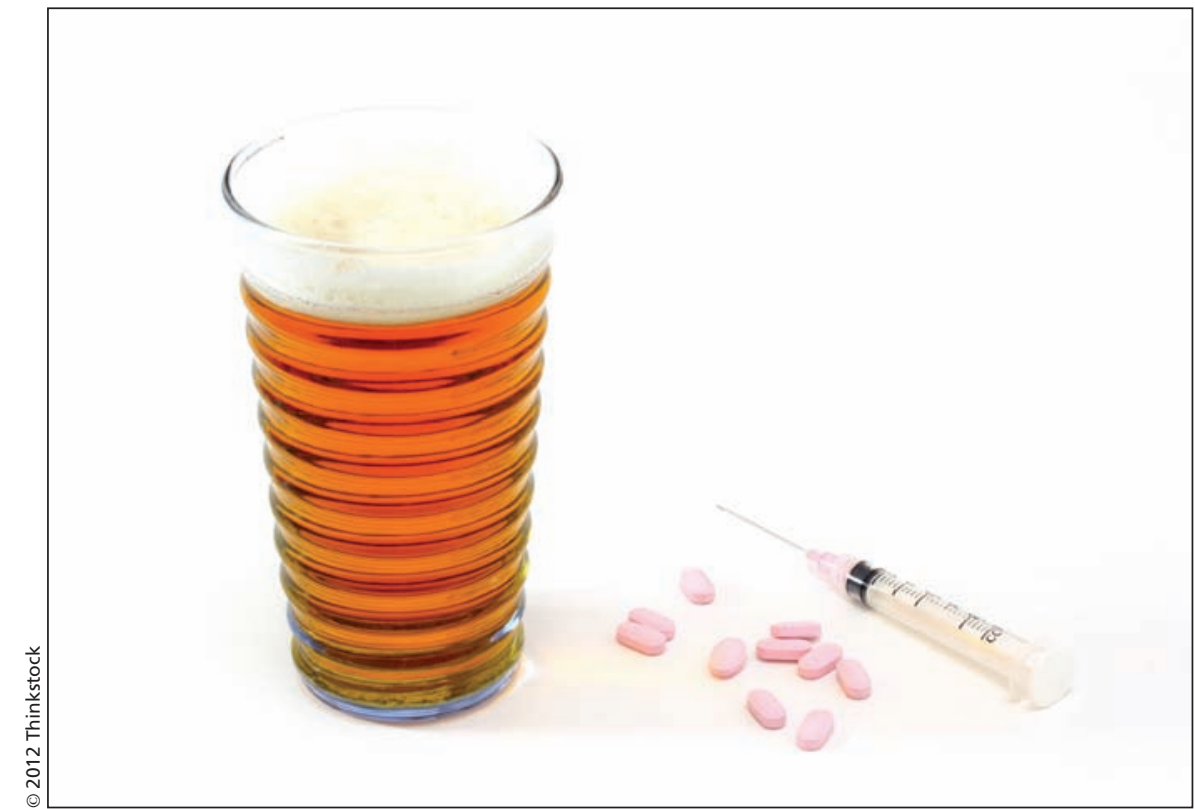

Background criminal record checks have proven an invaluable tool in tipping-off medical regulators in other jurisdictions about the need for remedial interventions in instances where a physician has had a substance abuse problem.

tion can tip off medical regulators to "intervene at an early stage to provide support and remediation for physicians whose performance is beginning to fall away from the required standard."

Fisher Brinkley says such remediation might involve mandating a physician to participate in a monitored treatment program for drug or alcohol problems, or to attend anger management therapy, she says.

Regulators have to "expect the unexpected," Nancy Kerr, executive director of the Idaho Board of Medicine, writes in an email. That might include a "trend in reckless driving or driving under the influence."

Although Canadian regulatory authorities are divided as whether monies should be spent on criminal record checks, international licensing bodies say the administrative and financial burden is nominal.

Moreover, they say, physicians aren't offended. "There is a sense among physicians that such checks are part of the privilege of being in a selfregulated profession," Carlson says.

Nor do checks appear to unduly delay licensure, although in some countries the process has been known to take up to six weeks, depending upon whether screening is conducted electronically. In Australia, "results are received for more than
$80 \%$ of checks within $24-48$ hours, so this has negligible impact on the timeframe for processing an application," Dr. Joanna Flynn, chair of the Medical Board of Australia, writes in a statement.

Several jurisdictions that currently review only first-time applicants for licensure indicate that they may expand the scope of their programs to include all practicing physicians.

North Carolina, for example, has partnered with an independent monitoring agency to conduct ongoing surveillance of charges and convictions among registered physicians.

Australia plans to conduct rolling audits of registered physicians seeking license renewal and will be consulting on means of undertaking international criminal record checks of physicians seeking to set up a shingle Down Under. — Lauren Vogel, CMAJ

CMAJ 2012. DOI:10.1503/cmaj.109-4114

Second of a three part series:

Part 1: Have you done time, doc? (www.cmaj.ca/lookup/doi/10.1503 /cmaj.109-4113).

Part 3: Are you kidding, doc? (www.cmaj.ca/lookup/doi/10.1503 /cmaj.109-4115). 